\title{
Blood Transfusion Requirements for Patients on Extracorporeal Membrane Oxygenation
}

\author{
Min Choi \\ Thomas Jefferson University, min.choi@jefferson.edu \\ Hitoshi Hirose, MD, PhD \\ Thomas Jefferson University, genex@nifty.com
}

Follow this and additional works at: https://jdc.jefferson.edu/si_ctr_2022_phase1

Part of the Surgery Commons, and the Translational Medical Research Commons Let us know how access to this document benefits you

\section{Recommended Citation}

Choi, Min and Hirose, MD, PhD, Hitoshi, "Blood Transfusion Requirements for Patients on

Extracorporeal Membrane Oxygenation" (2020). Phase 1. Paper 87.

https://jdc.jefferson.edu/si_ctr_2022_phase1/87

This Article is brought to you for free and open access by the Jefferson Digital Commons. The Jefferson Digital Commons is a service of Thomas Jefferson University's Center for Teaching and Learning (CTL). The Commons is a showcase for Jefferson books and journals, peer-reviewed scholarly publications, unique historical collections from the University archives, and teaching tools. The Jefferson Digital Commons allows researchers and interested readers anywhere in the world to learn about and keep up to date with Jefferson scholarship. This article has been accepted for inclusion in Phase 1 by an authorized administrator of the Jefferson Digital Commons. For more information, please contact: JeffersonDigitalCommons@jefferson.edu. 


\title{
SI/CTR Abstract
}

Word count: 250 words

\section{Blood Transfusion Requirements for Patients on Extracorporeal Membrane Oxygenation}

\author{
Min Choi, Hitoshi Hirose MD, PhD*
}

Department of Surgery, Thomas Jefferson University, Philadelphia, PA.

$\left({ }^{*}\right)$ indicates primary project advisor

Introduction: Extracorporeal membrane oxygenation (ECMO) is a rescue device used for cardiac and pulmonary dysfunction. Patients on ECMO often require blood transfusions from bleeding complications. Goals of the study are to determine: 1) transfusion requirements while on ECMO, 2) incidence of bleeding complications, 3) transfusion requirements for bleeding complications.

Methods: Packed Red Blood Cell (PRBC) transfusions and bleeding complications were identified by retrospective chart review of patients on ECMO from 2010 to 2018 at our institution. Patients were categorized into those who did not bleed (group A) and those who bled (group B). Site, incidence, and transfusion requirement for each bleeding event were determined.

Results: Among a total of 217 patients, we identified 62 patients (29\%) without bleeding complications (group A) and 155 patients (71\%) with bleeding complications (group B). PRBC transfusion requirement was higher in group B (1.6 PRBC/day) than group A (0.5 $\mathrm{PRBC} /$ day) $[\mathrm{p}=<0.0001]$. In group $\mathrm{A}$, number of $\mathrm{PRBC}$ requirements was $0.6 \mathrm{PRBC} /$ day for VA ECMO $(n=42)$ and $0.2 \mathrm{PRBC} /$ day for VV ECMO $(n=20)[p=0.0015]$. In group $B$, number of PRBC requirements was 1.8 PRBC/day for VA ECMO $(n=106)$ and 1.1 
PRBC/day for VV ECMO $(n=49)[p=0.0006]$. In group $B$, incidence and number of PRBC given per major bleeding complication during ECMO were: mediastinal/thoracic bleed (7.3 PRBC, $n=84$ ), Gl bleed (7.1 PRBC, $n=59$ ), cannulation site bleed (5.2 PRBC, $\mathrm{n}=88$ ), and ENT bleed (4.1 PRBC, $\mathrm{n}=103)$.

Discussion: Transfusion requirements increased once patients developed bleeding complications. Patients on VA ECMO required more PRBC/day compared to those on VV ECMO. 